\title{
The Improvement of Working Posture and Ergonomic Workplace Stretching Decreased Musculoskeletal Complaint and Fatigue and Increased Productivity of Nurses
}

\author{
Luh Gede Suwartini ${ }^{1 *}$, Ketut Tirtayasa ${ }^{2}$, and Luh Made Indah Sri Handari Adiputra ${ }^{3}$. \\ ${ }^{1}$ Hemodialysis Unit Department in Wangaya Regional Public Hospital (RSUD), Denpasar. \\ 2, Physiology Department, Medic and Health Science Faculty, Udayana University, Denpasar. \\ ${ }^{3}$ Ergonomics of Work Physiology Department, Postgraduate Program, Udayana University, \\ Denpasar. \\ *) Correspondence e-mail: lgs.nik888@gmail.com \\ doi: https://doi.org/10.24843/JEI.2020.v06.i02.p04
}

Article Received: 03 July 2020; Accepted: 13 October 2020 Published: 31 December 2020

\begin{abstract}
General fatigue complaints and musculoskeletal disorders are two of the most common symptoms experienced by dialysis nurses, as the products of the poor ergonomic working poses. Ergonomic intervention and stretching in the workplace are needed to reduce the symptoms. Unnatural pose has a potential to develop general fatigue and musculoskeletal disorders in hemodialysis room where each nurse in every shift is in charge to take care of four patients. The study aims to investigate the improvement of poses of work ergonomically by using ergonomic workplace stretching to reduce complaints in musculoskeletal and general fatigue which in turn can expectedly improve work productivity in hemodialysis room. This study is an experimental study with treatment by subject design. The study was conducted in hemodialysis unit in Wangaya Regional Public Hospital (WRPH) Denpasar from October until December 2019 with 11 people as the participants. As the result, there is no significant difference in the average of musculoskeletal complaints before working with $\mathrm{p}=0.350$ ( $>>0.05)$. Meanwhile, the average of musculoskeletal complaints of nurse after working shows a significant difference that is $\mathrm{p}=0.001(\mathrm{p}<0.05)$. The analysis result indicates that there is a significant decrease in musculoskeletal complaints, which is $36.18 \%$. The average of general fatigue before working shows no significant difference in score, that is $\mathrm{p}=0.350(\mathrm{p}>0.05)$. In the other side, there is a significant difference in score after working with $\mathrm{p}=0.001(\mathrm{p}<0.05)$. The analysis result reveals that there is a significant decrease in general fatigue for $66.97 \%$. A significant improvement is shown in the productivity average with $\mathrm{p}=0.001(\mathrm{p}<0.05)$. The conclusion of this study is the improvement in poses of work and ergonomic workplace stretching have reduced the complaints in musculoskeletal and general fatigue and also improve nurses' working productivity in hemodialysis unit.
\end{abstract}

Keywords: ergonomic workplace stretching, general fatigue, musculosceletal

\section{Perbaikan Sikap Kerja dan Ergonomic Workplace Streching Menurunkan Keluhan Muskuloskeletal dan Kelelahan serta Meningkatkan Produktivitas Kerja Perawat di Unit Hemodialisis RSUD Wangaya Kota Denpasar}

Sebagai upaya untuk meminimalkan keluhan kelelahan dan gangguan muskuloskeletal perawat hemodialisis akibat sikap kerja yang kurang ergonomis, diperlukan intervensi ergonomi terhadap perawat selama melakukan pekerjaannya melalui penggunaan kursi kerja dan workplace stretching setelah melakukan aktivitas. Sikap yang tidak alamiah berpotensi menimbulkan kelelahan dan gangguan muskuloskeletal di ruang hemodialisis RSUD Wangaya dimana perawat yang bekerja setiap shift adalah satu perawat melayani empat pasien. Tujuan penelitian adalah membuktikan 
perbaikan sikap kerja secara ergonomi menggunakan ergonomic workplace stretching untuk mengurangi keluhan muskuloskeletal dan kelelahan agar dapat meningkatkan produktivitas kerja perawat di ruang hemodialisis. Penelitian yang digunakan adalah penelitian ekperimental dengan menggunakan rancangan sama subjek. Penelitian dilaksanakan di unit Hemodialisis RSUD Wangaya Kota Denpasar, awal Oktober 2019 sampai dengan akhir Desember 2019 dengan jumlah sampel 11 orang. Hasil penelitian menunjukkan rerata keluhan muskuloskeletal sebelum kerja pada Periode I dan II tidak berbeda bermakna dengan nilai $t=0,980$ dan nilai $p=0,350(p>0,05)$. Rerata keluhan muskuloskeletal perawat sesudah kerja berbeda secara signifikan antara Periode I dan II dengan nilai $t=75,922$ dan nilai $p=0,0001(p<0,05)$. Hasil analisis menunjukkan bahwa terjadi penurunan keluhan muskuloskeletal yang signifikan antara Periode I dan II sebesar 36,18\%. Rerata kelelahan sebelum kerja pada Periode I dan II tidak berbeda bermakna dengan nilai $t=0,980$ dan nilai $p=0,350(p>0,05)$. Rerata kelelahan perawat sesudah kerja berbeda secara signifikan antara Periode I dan II dengan nilai $t=75,933$ dan nilai $p=0,0001$ ( $p<0,05$ ). Hasil analisis menunjukkan bahwa terjadi penurunan kelelahan yang signifikan antara Periode I dan II yaitu 66,97\%. Rerata produktivitas perawat meningkat signifikan antara Periode I dan II dengan nilai $t=7,206$ dan nilai $p=0,0001(p<0,05)$. Hasil analisis tersebut menunjukkan bahwa terjadi peningkatan produktivitas yang signifikan antara Periode I dengan II sebesar 9,09\%. Simpulan penelitian adalah perbaikan sikap kerja dan ergonomi workplace stretching dapat mengurangi keluhan muskuloskeletal dan kelelahan serta meningkatkan produktivitas kerja perawat di unit hemodialisis RSUD Wangaya Kota Denpasar. Penelitian ini diharapkan menjadi acuan perawat terutama dalam mengurangi keluhan muskuloskeletal dan kelelahan.

Kata kunci: kelelahan, muskuloskeletal, ergonomic workplace stretching, RSUD Wangaya.

\section{INTRODUCTION}

Health services can be conducted in groups which is a service managed by private or government at the hospital. Wangaya Regional Public Hospital (WRPH) is a type B government hospital which provides specialist health services for inpatient or outpatient with various service units, one of those is hemodialysis service. Hemodialysis service is provided in the hemodialysis unit/room for patients who needs dialysis therapy, such as kidney failure patient. Hemodialysis (HD) occurs in a long period and permanent to substitute the decreased kidney's function (Brenner \& Lazarus, 2012). Ideally, HD is proceeded for $10-15$ minutes/week, which means the patients need 4 - hours/week and about $2-3$ times of HD in a week (Suwitra, 2009).

Hemodialysis Unit in WRPH has fulfilled the minimum service standard in the regulation of Minister of Health of the Republic of Indonesia and provides the minimum service to the patients who need dialysis therapy. Hemodialysis Unit has been operating since August $18^{\text {th }}$ of 2006 and currently, there are 20 hemodialysis machines with 800 treatments. The patients who need hemodialysis will have two times hemodialysis treatment based on the schedule. The age range of patients who get hemodialysis treatment is from $18-75$ years old with the most etiology, such as diabetes mellitus (DM), hypertension, pyelonephritis chronic (PNC), glomerulonephritis chronic (GNC). The health workers who involved in giving hemodialysis treatment are one consultant doctor of kidney hypertension, one internist who is responsible in hemodialysis unit, two general professional practitioners as the executive doctors, 13 certificated nursing staffs, administration staff, and electromedical staff. The nursing staff is responsible in providing nursing care in pre, intra and post level of hemodialysis treatment. Each nurse has 6 hours/day ( 2 shift) and is responsible to $3-4$ patients.

The activities in providing nursing care to patients are: preparing the environment, such as comfortable bed, bulkhead for patient's privacy, light and temperature with operational standard; preparing dialysis machines which are ready used with rinse process (disinfectant 
and machine cleaning) and soaking (machine temperature, the dialyzer or artificial kidney humidification process); preparing patients, such as prior assessment in weight, vital sign measurement and take anamneses of patient complaints. Then, puncture in the patient's large blood vessels (arteries and veins) is done as the access of vascular in dialysis treatment. After the blood vessel access is complete, then the hemodialysis process is taken over by the machine until the target (time, weight and so on) is accomplished while nursing staffs observe the patients and machines continuously. There is no specific resting time while in charge in providing nursing care and nursing staff only use free time to take a break. Hemodialysis process is ended by taking off the vascular access, ensuring that there is no bleeding and the condition of the patients is stable.

Poses of work which is done by nursing staff in hemodialysis unit of WRPH is mostly unnatural. Standing position while working tends to bend their body for a long time is done when doing puncture of vascularizing access and taking off the vascular access and preventing bleeding. From the observation result, one series of puncture is occurred for the time average 6 minutes 64 seconds in one patient and continue to the other patients. The bending in poses of work is done to find the appropriate position due to the height of bed is lower than the reach of nursing staff's height (the bed is not adjustable) and the patients are frequently changing their position. To assess the nurses' working pose, Rapid Entire Body Assessment (REBA) is used which resulted in the final score of 8 , which means that the position has a high risk to cause musculoskeletal disorder and thus needs the improving treatments.

If the treatment is not provided, the nurses will remain suffer from discomfort, general fatigue and musculoskeletal complaints. Musculoskeletal Disorders (MSDs) is a complaint in skeletal muscles, which has a low until high complaints when the muscles experienced pressure for a long time (Kirkhorn, et.al., 2010). MSDs can cause complains which is caused by muscles damage, ligament, joints, bone, tendon, cartilage and spinal cord. MDSs is occurred on nursing staff who work in hemodialysis room. The interview results to 5 nursing staff shows that they experienced pain in the neck, shoulder, elbow and waist, however the observation used Nordic Body Map questionnaire and the lowest score is 71 and the highest is 96 . It can be interpreted that nurse staff has a high risk to experience musculoskeletal and improvement treatment needs to be immediately conducted.

Fatigues is related to physical and mental general fatigue which cause a decrease in physical performance, feeling tired, decreased in motivation and productivity (Setyawati, 2010). The fatigue level of 5 nursing staff in working after and before in hemodialysis room is assessed by using 30 item of rating scale questionnaire which cause the increase in nursing about $80 \%$. The average of resting pulse is $80 \mathrm{x} /$ minute and working pulse is $100-140$ beat/min, which shows medium-high workload. Base on those condition, nursing staff who work in hemodialysis room experiences several ergonomic problems and need intervention to reduce problems, the risk to musculoskeletal disorder, prevent work accident and improve working productivity.

In order to achieve the optimal work result, tools, work place design, procedure and work environment based on needs, anthropometric measures, natural poses of works and the maximum capacity of individual workers are needed, among those the priority for the improvement are poses of work and workplace stretching. The improvement of poses of work can be fixed with the adjustments between the anthropometric size of the nurse and the bed, the position of the patient and the field of work for nurse. The use of ergonomic working chair while doing puncture and other procedures is used compared doing the procedure while bending the body. Moreover, the intervention by giving ergonomic workplace stretching to hemodialysis nurse in before, during and after doing hemodialysis treatments can be applied to improve flexibility and help to relax the muscles after doing the treatment. Providing 
intervention will be built-in with standard operational procedure of nurse in hemodialysis room.

\section{METHOD}

The method of this study is experimental with treatment by subject design, where all subjects were assigned as control and treatment subjects at the different time period. The study was conducted in Hemodialysis Unit of WRPH on October until December 2019. Total sampling techniques is used in choosing the participants. Eleven of nurses who work during the puncture process of vascularization access has fulfilled the inclusion criteria. Nordic Body Map in 4 scales is used to measure body musculoskeletal experience of nurses. The 30 item of rating scale fatigue questionnaire is used to measure fatigue. Stopwatch is used to measure the duration of activity needed. Lux meter is used for measuring the light intensity in work place. Sound level meter used for measuring the noise intensity in work place. Humidity meter is used for measuring the room humidity in the work place, and camera is used to document the activity during research. Data obtained was analyzed using SPSS version 16.0 to test the set hypothesis with significant level $\mathrm{p}=0.05$.

\section{RESULTS AND DISCUSSION}

The age average of subject is $33.27 \pm 4.047$ years old. The age average in this study which include productive age while working (Depkes RI, 2015). Number of studies has stated that the range of productive age in ergonomic is around $31-44$ years old with the average is 37.11 years old (Yusuf, 2016), and this study states the average age is 34.89 years old (Dinata, et.al., 2015). This study show that average of age can be categorized as productive and has the ability to work in optimal way.

The average weight was $65.36 \pm 16.070 \mathrm{~kg}$, the average height was $163.45 \pm 7,06 \mathrm{~cm}$ and Body Mass Index (BMI) is $24.17 \pm 4.207 \mathrm{~kg} / \mathrm{m}^{2}$ with similar condition as the previous study which has been conducted in ergonomic about providing seat covers and stretching movements on drum carvers in Gianyar (Hamzah, 2018). It is supported with the number of BMI that shows the category nurse's body condition is normal and indicates the healthy physical condition while doing research (Depkes RI, 2015). The average result in work experience was 11.18 \pm 5.82 years and the range about $5-17$ years. This indicates that the subject was extremely experienced.

The data of research subject condition and environment condition in nurse working place that is in hemodialysis room can be seen in Table 1 and Table 2.

Table 1

The Data Result of Research Subject Condition(n=11)

\begin{tabular}{lc}
\hline \multicolumn{1}{c}{ Variable } & Average \pm Standard Deviation \\
\hline Age (years) & $33.27 \pm 4.047$ \\
Height $(\mathrm{cm})$ & $163.45 \pm 7.062$ \\
Weight $(\mathrm{kg})$ & $65.36 \pm 16.070$ \\
IMT $\left(\mathrm{kg} / \mathrm{m}^{2}\right)$ & $24.17 \pm 4.207$ \\
Work Experience (years) & $11.18 \pm 5.810$ \\
\hline
\end{tabular}


Table 2

The Data Result of Environment Condition in Working Place of Hemodialysis Nurse $(n=11)$

\begin{tabular}{|c|c|c|c|c|}
\hline \multirow{2}{*}{ Variable } & Perioe I & Period II & \multirow{2}{*}{$\mathrm{t}$ value } & \multirow{2}{*}{$\mathrm{p}$ value } \\
\hline & Average $\pm S B$ & Average $\pm S B$ & & \\
\hline Temperature $\left({ }^{0} \mathrm{C}\right)$ & $22.43 \pm 0.081$ & $22.45 \pm 0.083$ & 0.415 & 0.695 \\
\hline Relative Humidity (\%) & $54.70 \pm 1.204$ & $55.40 \pm 0.219$ & 1.204 & 0.282 \\
\hline Light Intensity (lux) & $100.83 \pm 2.041$ & $201.67 \pm 4.082$ & 50.243 & 0.000 \\
\hline Noise (dB) & $52.00 \pm 2.450$ & $51.67 \pm 2.065$ & 0.284 & 0.788 \\
\hline
\end{tabular}

The compatibility test between Period I and Period II with $\mathrm{p}=0.365$ ( $\mathrm{p}>0,05)$ means that the temperature in Period I and Period II is comparable or provide the similar effect to the change of variable. The compatibility test between Period I and Period II with $p=0.282(p>0.05)$ shows that the humidity is similar to the change of related variable. The compatibility test between Period I and Period II with $\mathrm{p}=0.695$ ( $\mathrm{p}>0.05$ ) indicates that the light intensity is similar to the related variable change. The compatibility test between Period I and Period II with $\mathrm{p}=0.788(\mathrm{p}>0.05)$ means that it is comparable or provide the similar effect to the change of related variable.

Table 3

The Analysis Result of Nurse's Musculoskeletal Complaint, Fatigue and Work Productivity ( $\mathrm{n}=11$ )

\begin{tabular}{lccc}
\hline \multicolumn{1}{c}{ Variable } & $\begin{array}{c}\text { Period I } \\
\text { Rerata } \pm \text { SB }\end{array}$ & $\begin{array}{c}\text { Period II } \\
\text { Rerata } \pm S D ~\end{array}$ & Changes \\
\hline $\begin{array}{l}\text { Musculoskeletal Complaints } \\
\text { (Before Working) }\end{array}$ & $28.91 \pm 0.539$ & $29.27 \pm 0.786$ & $1.25 \%$ \\
$\begin{array}{l}\text { Musculoskeletal Complaints } \\
\text { (After Working) }\end{array}$ & $41.73 \pm 1.104$ & $39.36 \pm 0.505$ & $-5.68 \%$ \\
$\begin{array}{l}\text { Musculoskeletal Complaints } \\
\text { (Difference) }\end{array}$ & $12.82 \pm 1.168$ & $10.10 \pm 0.700$ & $-21.22 \%$ \\
$\begin{array}{l}\text { Fatigue } \\
\text { (Before Working) }\end{array}$ & $30.11 \pm 0.151$ & $30.27 \pm 0.467$ & $0.50 \%$ \\
$\begin{array}{l}\text { General fatigue (After } \\
\text { Working) }\end{array}$ & $66.09 \pm 1.578$ & $42.18 \pm 0.603$ & $-36.18 \%$ \\
$\begin{array}{l}\text { Fatigue (Difference) } \\
\text { Productivity }\end{array}$ & $35.98 \pm 1.554$ & $11.91 \pm 0.700$ & $-66.90 \%$ \\
\hline
\end{tabular}

Based on the analysis result above in Table 3, the difference of musculoskeletal complaints in Period I and Period II is decreased for $-21.22 \%$. The difference of fatigue is also decreased for $-66.90 \%$, in the other side nurse' productivity level in the time duration is decreased for $-4.34 \%$. 
Table 4

Normality Test in Nurse's Musculoskeletal Complaints, Fatigue and Work Productivity $(\mathrm{n}=11)$

\begin{tabular}{lc}
\hline \multicolumn{1}{c}{ Variable } & Average \pm SD \\
\hline Musculoskeletal Complaints Before Working (Period I) & $28.91 \pm 0.539$ \\
Musculoskeletal Complaints After Working (Period I) & $41.73 \pm 1.104$ \\
The Difference of Musculoskeletal Complaints (Period I) & $12.82 \pm 1.168$ \\
Musculoskeletal Complaints Before Working (Period II) & $29.27 \pm 0.786$ \\
Musculoskeletal Complaints After Working (Period II) & $39.36 \pm 0.505$ \\
The Difference of Musculoskeletal Complaints (Period II) & $10.10 \pm 0.700$ \\
Fatigue Before Working (Period I) & $30.11 \pm 0.151$ \\
Fatigue After Working (Period I) & $66.09 \pm 1.578$ \\
The Difference of Fatigue (Period I) & $35.98 \pm 1.554$ \\
General fatigue Before Working (Period II) & $30.27 \pm 0.467$ \\
General fatigue After Working (Period II) & $42.18 \pm 0.603$ \\
The Difference of Fatigue (Period II) & $11.91 \pm 0.700$ \\
Productivity (Period I) & $4.84 \pm 0.336$ \\
Productivity (Period II) & $4.63 \pm 0.304$ \\
\hline
\end{tabular}

Based on the analysis above, it shows that the data before, after and difference in musculoskeletal complaints, general fatigue and productivity in Period I and Period II is normally distributed ( $p>0.05)$, and continued with paired t-test with $5 \%$ significance.

Table 5

Hypothesis Test Result in Nurse's Musculoskeletal Complaints, General fatigue and Work Productivity $(n=11)$

\begin{tabular}{lcccc}
\hline \multirow{1}{*}{ Variable } & Period I & Period I & & \\
\cline { 2 - 3 } & Average \pm SB & Average \pm SD & t value & p value \\
\hline $\begin{array}{l}\text { Musculoskeletal Complaints } \\
\text { (Before Working) }\end{array}$ & $28.91 \pm 0.539$ & $29.27 \pm 0.786$ & 1.491 & 0.167 \\
$\begin{array}{l}\text { Musculoskeletal Complaints } \\
\text { (After Working) }\end{array}$ & $41.73 \pm 1.104$ & $39.36 \pm 0.505$ & 6.500 & 0.000 \\
$\begin{array}{l}\text { General fatigue } \\
\text { (Before Working) }\end{array}$ & $30.11 \pm 0.151$ & $30.27 \pm 0.467$ & 0.980 & 0.350 \\
$\begin{array}{l}\text { General fatigue (After } \\
\text { Working) }\end{array}$ & $66.09 \pm 1.578$ & $42.18 \pm 0.603$ & 75.922 & 0.000 \\
\begin{tabular}{l} 
Productivity \\
\hline
\end{tabular} & $4.84 \pm 0.336$ & $4.63 \pm 0.305$ & 7.206 & 0.000 \\
\hline
\end{tabular}


Table 5 shows the average of nurse's musculoskeletal complaints is comparable. It is used to decide the decrease of musculoskeletal complaints between Period I and Period II based on hypothesis test after working, the average of musculoskeletal complaints is significantly different between Period I and Period II with $\mathrm{t}=6.500$ and $\mathrm{t}=0.000(\mathrm{p}<0.05)$. The result also shows a significant decrease in musculoskeletal complaints between Period I and Period II for $-21.22 \%$. The nurse's general fatigue average is comparable. It is used to decide the decrease of fatigue between Period I and Period II based on the result of hypothesis test in fatigue average. The average of nurse's fatigue after working is significantly different between Period I and Period II with $\mathrm{t}=75.922$ and $\mathrm{p}=0.000(\mathrm{p}<0.05)$. It indicates the significant decrease between Period I and Period II, that is $-66.90 \%$. The nurse's productivity average is decreasing in duration, but increasing in work productivity, this improvement is significant between Period I and Period II with $\mathrm{t}=7.206$ and $\mathrm{p}=0.000(\mathrm{p}<0.05)$. It indicates that there is a significant improvement in productivity between Period I and Period II or decreasing in time duration for $-4.34 \%$.

Ergonomic workplace stretching is a stretching exercise that workers can do to prevent musculoskeletal pain, neck and shoulder injuries. This stretch is done after the nurse has finished doing punctures with ten movements twice in 20 seconds (Anderson, 2010). Related with this study, several researchers reported that the complaints about respondents' muscle disorders occurred in the lower part of the waist muscles (Nuryaningtyas \& Martiana, 2014). This is due to conditions of bending the body for $20-60^{\circ}$ while working. This situation results in an increased risk of musculoskeletal disorders (Wicaksona, 2012). Another study states that a large reduction in musculoskeletal complaints in nurses who are given workplace stretching exercise (WSE) interventions can provide relaxation to muscles and joints to increase blood flow and reduce pain or musculoskeletal complaints in nurses (Syafrianto \& Zulfa, 2019).

In principle, the stretching movement is located in the neck to the leg muscles, part of muscles that experience spasm cause a shortening of the muscle fibers because the myofilaments webbing overlaps one another. When the resistance stretching is done with several seconds duration and the position of muscle is long, the structure of the muscle fiber, especially the sarcomere, is stretched because of the overlapping is less than usual, which affect the structure of the muscle fiber to lengthen and muscle spasm is reduced. Related to this, the cause of fatigue at work are the length of work, physical and mental burdens, environment condition, such as working weather, noise and lighting, psychological responsibilities, worry and illness, and nutrition condition. Several researchers state that the subjective fatigue use a method or parameter IFRC which is experienced to the tired nurses while working (Perwitasari \& Tualeka, 2018).

In general, productivity can be defined as the relation between certain value of input and output. Working productivity shows how the nurse do their job. The productivity of work is caused by the body attitude and paying attention to the condition and situation of burden on the body, the scope and the type of work. The use of a working chair when doing a puncture and ergonomic workplace stretching while breaks in this study was reduce the fatigue of the muscles. Other study state that the environment of the workplace including external factors that can affect a person's motivation and environmental factors, such as training equipment, work facilities and infrastructure for employees who are carrying out their own work (Kawarimi, 2012). The result of examining the coefficient parameter of workload on the nurse's work productivity prove the positive impacts with the score 0.203 , and t-statistic is 2,091 . Those scores are above the critical score that is 1,96 (Wahyudi \& Gunarto, 2019). This assessment shows that the increased workload also causes the increase in productivity.

\section{CONCLUSION}


It can be concluded that the improvement of poses of work and ergonomic workplace stretching can reduce musculoskeletal complaints, fatigue and improved the nurse's working productivity. The result of this study is expected to be a reference for the nurse, especially in reducing musculoskeletal complaints and fatigue, and as a guideline to prevent and manage the risk.

\section{REFERENCES}

Anderson, B. 2010. Stretching in The Office. Jakarta: Serambi Ilmu Semesta.

Brenner, B.M., and Lazarus, J. 2012. Gagal Ginjal Kronik dalam Prinsip-Prinsip Ilmu Penyakit Dalam Harrison. 13th edn. Jakarta: EGC.

Dinata, I.M.K., Adiputra, N., and Adiatmika, I. P. 2015. Sikap Kerja Duduk-Berdiri Bergantian Menurunkan Kelelahan, Keluhan Muskuloskeletal Serta Meningkatkan Produktivitas Kerja Penyetrika Wanita di Rumah Tangga. Jurnal Ergonomi Indonesia. Vol. 1(1):3237.

Hamzah, A. 2018. "Pemberian Alas Duduk dan Mc Kenxie Exercise Menurunkan Ketegangan Otot dan Keluhan Muskuloskeletal serta Meningkatkan Produktivitas Kerja Pengukir Gendang Tambur di UD Budi Luhur Gianyar" (thesis0 Denpasar: Program Pascasarjana Universitas Udayana.

Kadarisman, M. 2012. Manajemen Pengembangan Sumber Daya Manusia. Jakarta: PT. Raja Grafindo Persada.

Kirkhorn, S.V., Richardson, G.E., and Banks, R. 2010. Ergonomic Risks and Musculoskeletal Disorders in Production Agriculture: Recommendation for Effective Research to Practice. Journal of Agromedicine. Vol. 15(3):281-299. doi: 10.1080/1059924X.2010.488618.

Nuryaningtyas, B. M. and Martiana, T. 2014. Analisis Tingkat Musculoskeletal Disorders (MSDs) dengan The Rapid Upper Limbs Assessment (RULA) dan Karakteristik Individu Terhadap Keluhan MSDs. The Indonesian Journal of Occupational Safety and Health. Vol. 3(2):160-169.

Perwitasari, D. and Tualeka, A.R. 2018. Faktor Yang Berhubungan Dengan Kelelahan Kerja Subyektif Pada Perawat Di RSUD Dr. Mohamad Soewandhie Surabaya. The Indonesian Journal of Occupational Safety and Health. Vol. 6(3): 362. doi: 10.20473/ijosh.v6i3.2017.362-370.

Depkes RI. 2015. Profil Kesehatan 2015. Departemen Kesehatan RI.

Setyawati. 2010. Selintas Tentang Kelelahan Kerja. Yogyakarta: Graha Ilmu.

Suwitra, K. 2009. Penyakit Ginjal Kronis. Jakarta: Interna Publishing.

Syafrianto, E., K.H, P. and Zulfa, Z. 2019. Pengaruh Workplace Stretching Exercise (WSE) dan Heat Therapy (Hot Pack) terhadap Keluhan Muskuloskletal pada Perawat Tahun 2019. Jurnal Ilmiah Universitas Batanghari Jambi. Vol. 19(3):678. doi: 10.33087/jiubj.v19i3.749.

Wahyudi, C. T. and Gunarto, C. S. 2019. Produktivitas Kerja Perawat Ruang Rawat Inap. Jurnal Ilmiah Ilmu Keperawatan Indonesia. Vol. 9(01):550-562. doi: 10.33221/jiiki.v9i01.210.

Wicaksona, B. 2012. "Faktor yang Berhubungan dengan Gangguan Nyeri Punggung Bawah pada Bidan saat Menolong Proses Persalinan di RSUD Bhakti Dharma Husada Surabaya" (skripsi). Surabaya: Universitas Airlangga.

Yusuf, M. 2016. "Desain Alat Pelubang Plastik Mulsa dan Sistem Kerja dengan Intervensi Ergonomi Meningkatkan Produktivitas Kerja Petani di Bedugul Bali" (disertasi). Denpasar: Program Pascasarjana Universitas Udayana. 